\title{
Correspondence
}

\section{STATUTORY INTERPRETATION}

\section{Dear Sir}

I regret that I consider it necessary to lodge a protest against the article 'Statutory Interpretation' by Alida Wilson ((1987) 7 LS 62), in that it seriously misrepresents the nature of my textbooks Statute Law (2nd edn, 1983) and Statutory Interpretation (1984).

The article describes these textbooks as 'proposals', and discusses whether or not they should be 'adopted'. The later book, it says, sets out the rules, principles, presumptions and canons which as I see it might, given the new approach I am supposed to be advocating, be used to guide the application of legislation. But, the article says, they should not be so adopted because this would take away responsibility from parliament, is not in accordance with 'the general ideal for the interpreterjudge', and takes us beyond interpretation into the realm of remedial action. Instead, says Alida Wilson, provision should be made for the judiciary formally to refer defective statutes back to parliament for amendment.

This is the ordinary language of academic discussion, where the choice is between alternative law reform proposals. But the choice here is not like that at all. It is between the present system, described in my books, and some possible alternative system advocated by Alida Wilson. This mistake is likely seriously to mislead readers about the essential nature of my books and thus damage their reputation. I trust therefore that you will permit me to correct it by the publication of this letter.

My earlier book, though mainly descriptive of the present system, does it is true contain a number of reform proposals. They are however clearly identifiable as such (see the index entry 'Reform, Proposals for'). The later and more substantial work, which takes the form of a code of 396 sections with a critical commentary, is wholly expository of the existing system. As reviewers without exception have perceived, it is not speculative. Being a codification of the present law of statutory interpretation, it is as suitable for enactment by parliament as any other codified version of the law would be. As a parliamentary draftsman of long experience, I drafted it in the same way, and with the same attention to accuracy in reproducing the law, as I have drafted other codifying provisions later enacted by parliament. It is basically a standard textbook on judicial techniques of statutory interpretation as they currently apply in Britain and the Commonwealth, and has been so received by reviewers and commentators. For example the leading textbook on legislative drafting in Britain and the Commonwealth includes it as the sole book on statutory interpretation in a reading list of books for draftsmen which 'should be regarded as essential equipment' (see 
Thornton, Legislative Drafting (3rd edn, 1987) p 111). Its nature is plainly stated in the Introduction ( $\mathrm{p} x \mathrm{xviii}$ )-

'This Code accordingly sets out the current principles governing the construction of Acts and other legislative instruments, as laid down or adopted by the courts (with some slight help from parliament). The intention is that the Code should be self-consistent. Contradictory utterances cannot both be right, and so cannot both be law.'

This surely makes it clear that, except insofar as I may have made mistakes in transcribing the current law of statutory interpretation (which is not suggested), my code faithfully reproduces it - including enacted law such as the Interpretation Act 1978. The citation of over 2,000 cases and over 1,000 Acts bears this out.

I annually update the book in an article in The All England Law Reports Annual Reviewe. In the latest one, covering cases reported in the All England Reports in 1986, no less than 60 such cases are described as bearing on the subject of statutory interpretation, covering 48 sections out of the 396 in my code. My work in compiling these articles has enabled me to verify the correctness of the code in reproducing existing law. In only one instance have I found any alteration needed, and that was due to a development of the law made by the Divisional Court in $R v$ Horseferry Road Justices, exp Independent Broadcasting Authority [1987] QB 54.

Yours faithfully

Francis Bennion

Dr Alida Wilson has seen the above letter and states that she wishes to leave the question raised to readers of $\mathrm{Mr}$ Bennion's valuable books and her own article $-\mathbf{E d}$. 